\title{
OPAC 2.0 az ELTE-n
}

\section{Webkettes technológiákra épülő VuFind könyvtári keresőszoftver}

\section{A web 2.0-tól az OPAC 2.0-ig}

A web 2.0 elnevezés 2001-ben hangzott el elöször, és attól kezdve rohamosan terjedni kezdett. ${ }^{1}$ A kifejezés olyan közösségre épülő web alapú szolgáltatások gyüjtöneve, ahol a felhasználók közösen készítik a tartalmakat vagy osztják meg egymás információit. A web 2.0 könyvtári szolgáltatásokra való kiterjesztéséből született a könyvtár 2.0 elnevezés, melyben az információáramlás már nem egyirányú, a felhasználói közönség maga is alakítja a könyvtári szolgáltatásokat, s így fokozódik a közösségi részvétel, a visszajelzés. A web 2.0-s lehetőséggel az online katalógusok (Online Public Access Catalog, OPAC) is nagyobb felhasználói élményt nyújtanak, úgymond közösségibbé válnak például az olvasó számára fontos, szürt információk megjelenítésével, vagy a tartalom szabad címkézésével.

Könyvtári oldalról alapvető, megoldandó feladat, hogy az olvasónak ne kelljen több adatbázisban, katalógusban keresni, ha információhoz szeretne jutni. Ennek technikai megoldása a közös keresők, a discovery eszközök használata, amelyek egypontos keresési felületet biztosítanak a könyvtár adatbázisai számára. Alkalmazásukkal tehát többféle könyvtári rendszert kell „közös nevezőre” hozni. Amellett, hogy rövidül a keresési idő, előnye, hogy a web2-es kényelmi szolgáltatások könnyebben integrálhatók. Hátránya viszont, hogy sok a duplum, amit szürni kell, és a rekordokat minőségi ellenőrzésnek kell alávetni. ${ }^{2}$

A VuFind egy nyílt forráskódú könyvtári információs portál, amelyet a Villanova Egyetem fejlesztett ki 2007-ben PHP programozási nyelven. Adatbázisként MySQL-t vagy PostgreSQL-t használ, a keresés indexeléséhez Solr ${ }^{3}$ eszközt alkalmaz. ${ }^{4}$

Az ELTE Egyetemi Könyvtár a VuFind rendszer implementálása mellett döntött. A jelenlegi fejlesztési fázisban a kollégákat bevonva belső tesztelést végzünk, és a tervek szerint 2017-ben tesszük elérhetővé az Egyetemi Könyvtári

${ }^{1}$ O'Reilly, Tim: What Is Web 2.0? Design Patterns and Business Models for the Next Generation of Software. Forrás: http://www.oreilly.com/pub/a/web2/archive/what-is-web-20.html (2016. szeptember 10.)

${ }^{2}$ Wilson, Katie: OPAC 2.0: Next generation online library catalogues ride the Web 2.0 wave! = Online Currents, 21. vol . 2007. 10. no. 406-413. p. Forrás: http://epubs.scu.edu.au/lib_pubs/11 (2016. augusztus 25.)

${ }^{3}$ A Solr nyílt forráskódú keresőplatform, mely Java programozási nyelven íródott. Forrás: http://lucene.apache.org/solr (2016. augusztus 22.)

${ }^{4}$ Ismertetés: https://vufind.org/vufind (2016. augusztus 22.) 
Szolgálat (EKSZ) megújult portálján keresztül, kezdetben nyilvános tesztelés céljából. Az esetlegesen felmerülő problémák javítása folyamatosan történik, a tervezett fejlesztéseket pedig müködés közben valósítjuk meg.

\section{Miért a VuFind?}

A VuFind mellett két fizetős szolgáltatást is teszteltünk, az EBSCO Discovery Service-t (EDS) és a Summont (Serials Solutions).

A nyílt forráskódú rendszerekkel már vannak pozitív tapasztalataink, hiszen az intézményi repozitóriumunknak, az ELTE Digitális Intézményi Tudástárnak (EDIT) is egy nyílt forráskódú szoftver, a DSpace ${ }^{5}$ az alapja, ezért bizakodva próbáltuk ki. A VuFind jól kombinálható a fizetős komplex keresőkkel, az EDS-t a tesztelési időszakra sikerrel implementáltuk a VuFindba. A VuFind lehetővé teszi a különböző metaadatformátumok helyi és külső források találatainak együttes elérését. A választás mellett szólt az is, hogy nagy a felhasználó könyvtárak száma, melyek között hazai példák is vannak, például a Debreceni Egyetem Egyetemi és Nemzeti Könyvtár (DEENK) és az Országos Széchényi Könyvtár (OSZK). Fontos számunkra továbbá, hogy a szoftver igényeink szerint alakítható, reszponzív, a legkülönfélébb eszközökön is optimális megjelenésü legyen. A keresést, böngészést az OAI-PMH (Open Archives Initiative Protocol for Metadata Harvesting) protokoll használatával learatott rekordok közös Solr adatbázisba való betöltése teszi lehetővé.

\section{A VuFind az ELTE-n}

Amikor elkezdtünk a VuFinddal dolgozni, nem gondoltuk, hogy az egyik legnagyobb kihívást a kereső elnevezése fogja jelenteni.

A könyvtáros szakmában tapasztalt változásoknak köszönhetően az utóbbi időben jelentősen bővült fogalmi készletünk. A nemzetközi szakirodalomból átvett kifejezésekre több fordítási kísérlet is születik, illetve előfordul, hogy az idegen elnevezés is elfogadottá válik. Az újgenerációs OPAC-okat hívhatjuk komplex adatbázis-keresőknek, discovery eszközöknek, vagy épp használhatjuk a discovery tools kifejezést. Mindemellett az általunk kialakított, személyre szabott rendszernek szeretnénk egy rövid, de kifejezö, az olvasók számára is érthető és elfogadott nevet adni. Az általunk jelenleg alkalmazott ELTE EKSZ metakereső elnevezés terveink szerint nem a végleges név, tehát tekinthető egyfajta munkacímnek, mely nagy valószínüség szerint a közeljövőben változni fog. Maga a VuFind rendszer elnevezése a fejlesztő Villanova University kezdőbetüiből és az angol find ('talál, megtalál') szóból született. Néhány külföldi felhasználó ezt a mintát követve nevezte el saját implementációját, például a Technische

${ }^{5}$ A DSpace közösség által fejlesztett nyílt forráskódú adattár alkalmazás, melyet a DuraSpace támogat. 
Universität Darmstadt TUFind névre, a Technische Hochschule Mittelhessen pedig THMFindra keresztelte keresőjét.

Jelenleg tehát az ELTE EKSZ metakereső néven futó ELTE-s VuFind - vagy, ha úgy tetszik, ELTEFind - fejlesztésén, testreszabásán dolgozunk. A kezdőoldal (1. ábra) megjelenésén nem sokat változtattunk, így a négy egységre - fejléc, keresősáv, böngészési lehetőségek, egyéb keresési, böngészési lehetőségek mellett segítséget nyújtó menüpontok - való tagolás is változatlanul maradt.

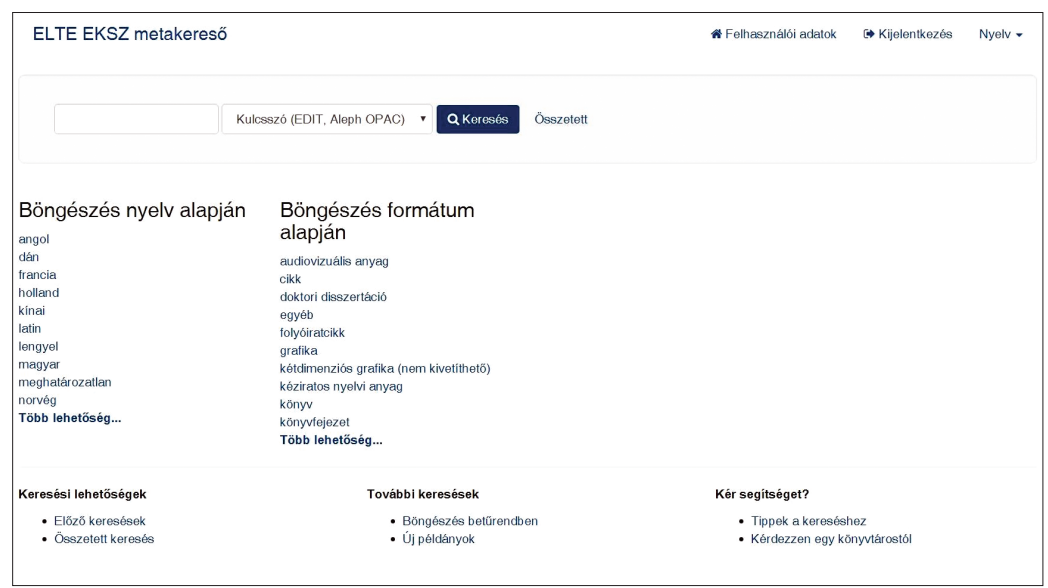

1. ábra. A VuFind kezdőoldala

Az egyszerú és az összetett keresés mellett nyelv és formátum szerinti böngészésre is van lehetőség. Megtekinthetők az előző keresések, az új példányok, vagy böngészhetünk betürendben. Beépített súgó is rendelkezésre áll Tippek a kereséshez elnevezés alatt, továbbá elérhető a Kérdezzen egy könyvtárostól funkció is, amellyel az Egyetemi Könyvtárinfo@lib.elte.hu e-mail címére lehet kérdést küldeni. Kinézetben az egyszerüségre és átláthatóságra törekszünk, igyekszünk a lehető legjobban kihasználni a rendszer adta lehetőségeket.

\section{A VuFind föbb jellemzői}

Az elavult keresési technológiák kiváltására létrejött, Google által inspirált discovery eszközök mind hasonló jellemzőkkel rendelkeznek, így a VuFind sem kivétel ez alól. A rendszer lehetővé teszi a felhasználó számára, hogy keressen egy alap keresőmezőben, majd a találati halmazt úgynevezett facetták segítségével szúkítse. Intézmény, formátum, szerző, nyelv és megjelenés éve szerint finomítható a keresés, de konfigurálható, egyéni igényekre szabható. A találati halmazban sárga háttérszínnel jelennek meg a keresési kifejezésnek megfelelő szavak. Az alábbi képen (2. ábra) egyszerü keresést végeztünk Arany Jánosra, majd a találati halmazt szerző szerint szükítettük (William Shakespeare). 


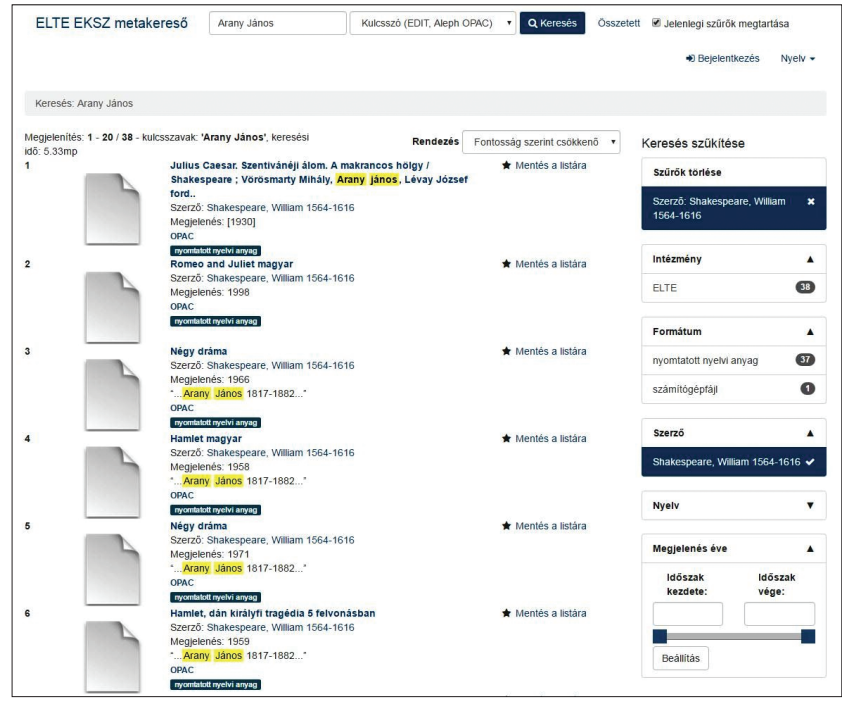

2. ábra. Keresés szükítés facetták segítségével

A találati oldalon a föbb és részletes adatok mellett meg tudja jeleníteni a rekord aktuális példánystátuszát, helyét. Az alábbi képen (3. ábra) egy tétel/rekord úgynevezett teljes nézetét látjuk. Amikor megtekintünk egy tételt, a rendszer a hasonló tételek listázásával javaslatokat ad további böngészéshez. A hasonló tételek két helyen is megjelennek, egyrészt - az asztali felületet használva - jobb oldalon listaszerüen, másrészt az alsó menüpontoknál - ahol a tételhez kapcsolódó információkat találjuk - indexképekkel.

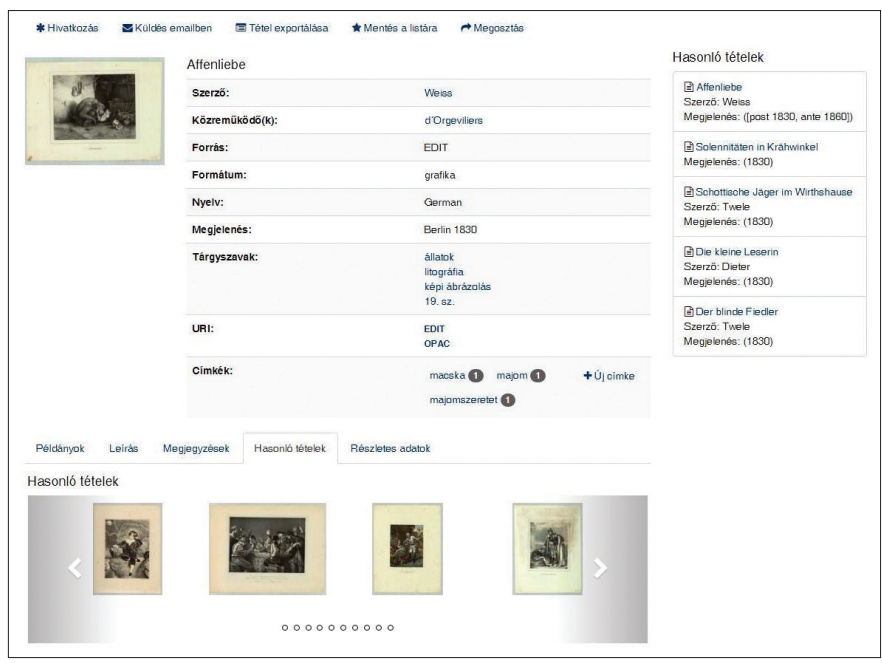

3. ábra. Tétel teljes nézete 
A tételeket saját listákba rendezhetjük a kis csillag mellett látható Mentés a listára hiperhivatkozásra kattintva, melyre mind a találati oldalon, mind a rekordnézet oldalon lehetőség van. A listára mentés alkalmával címkéket és megjegyzéseket is hozzáfüzhetünk a tételekhez (4. ábra). A listák folyamatosan bővíthetők, módosíthatók, illetve törölhetők, használatával elkerülhető például a hivatkozáskezelő szoftverek bizonyos funkcióinak alkalmazása, amelyek sok felhasználó számára túl bonyolultak, kényelmetlenek.

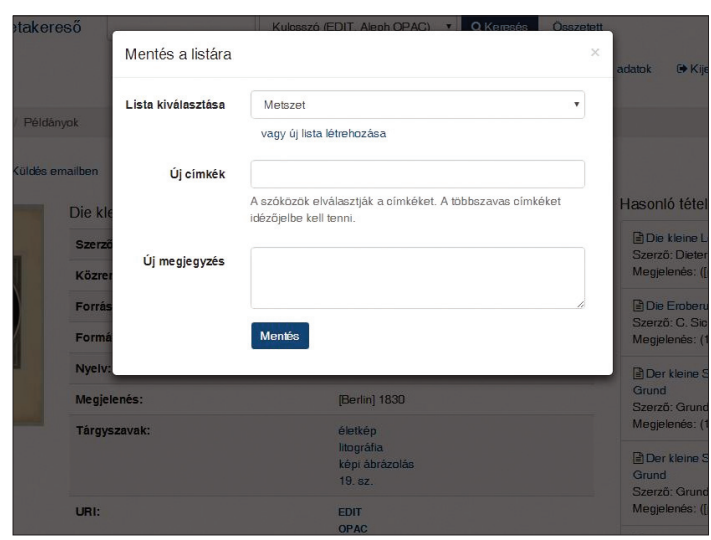

4. ábra. Tétel listába mentése

Az alábbi képen (5. ábra) egy olyan tétel látható, amely egy Metszet nevü listába van mentve. A rekord teljes nézeténél megjelenik a mentés helye, vagyis a lista neve, melyre kattintva az Elmentett példányokhoz irányít. A listákat itt szerkeszthetjük, törölhetünk belőlük számunkra feleslegessé vált tételeket, exportálhatjuk, nyomtathatjuk a lista egészét vagy egy részét (6. ábra).

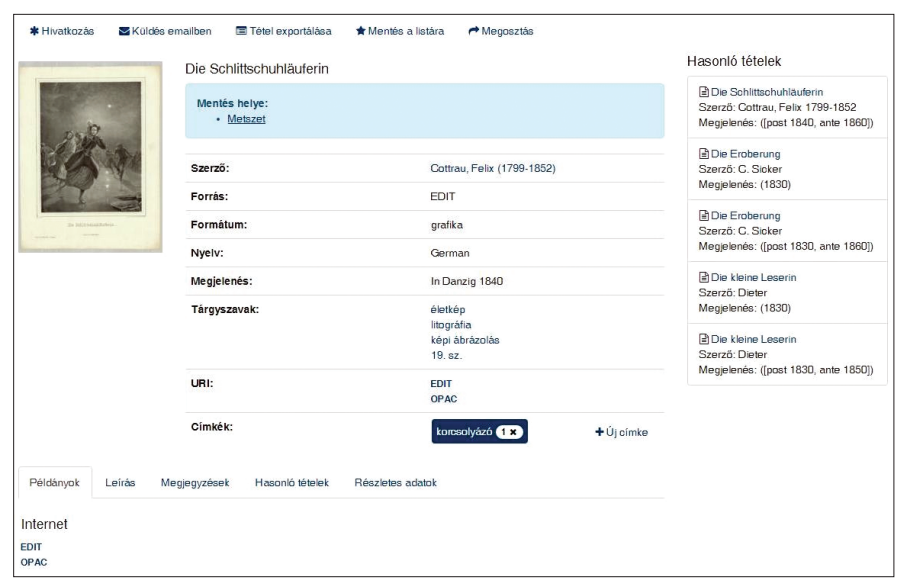

5. ábra. Tétel a listában 


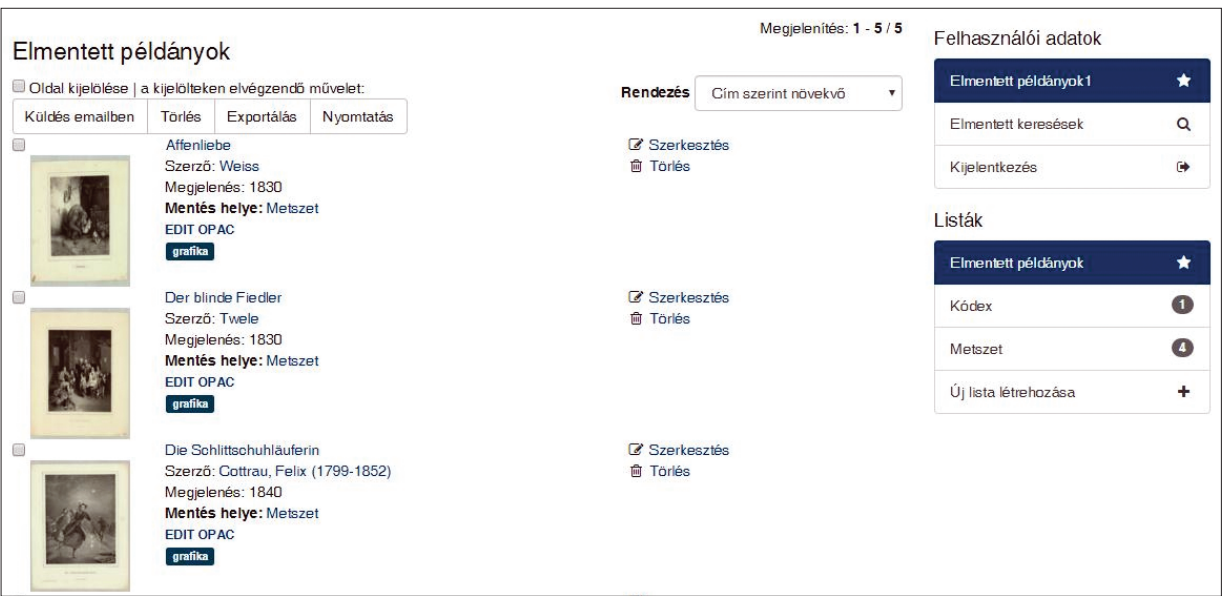

6. ábra. Elmentett példányok

A keresés mellett többféle szempont szerinti böngészésre is van lehetőség. A föoldalról indulva nyelv vagy formátum szerint tudunk böngészni, a betürendes böngészésnél választhatunk, hogy témakör, szerző vagy cím szerint szeretnénk áttanulmányozni a kínálatot (7. ábra).

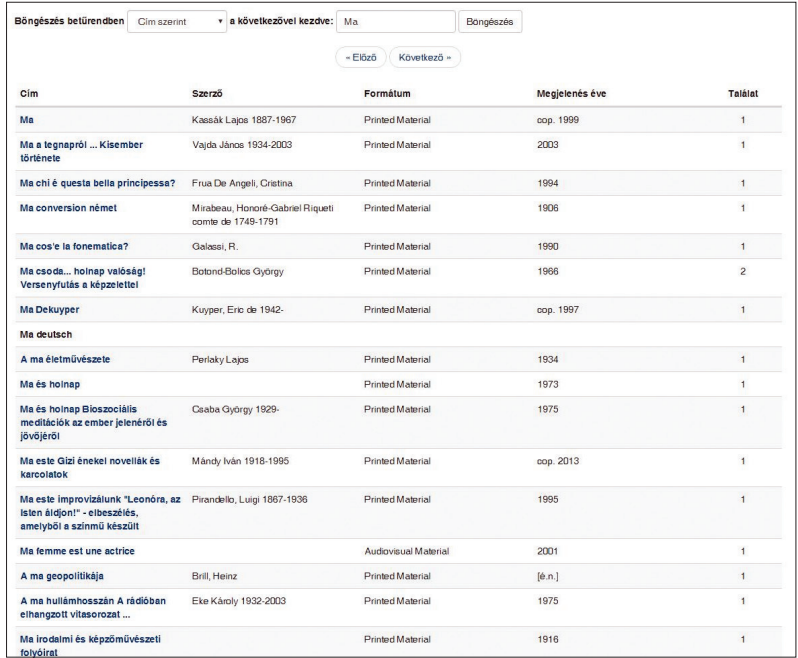

7. ábra. Böngészés cím szerint

Lehetőség van az újonnan betöltött példányok megtekintésére is. Kilistázhatjuk az előző napon, az előző 5 napon, illetve az előző 30 napon betöltött rekordokat (8. ábra). A kapott listát rendezhetjük relevancia vagy dátum szerint, illetve szükíthetjük a facetták segítségével. 


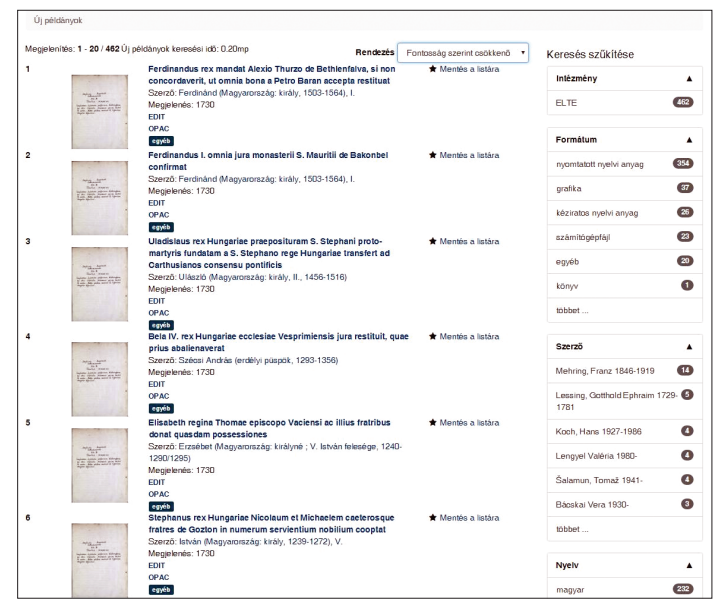

8. ábra. Új példányok böngészése

A tételeket, attól függetlenül, hogy saját listára mentettük vagy sem, megjegyzésekkel és címkékkel láthatjuk el (9. ábra). Természetesen ehhez és a listakészítéshez is regisztráció és bejelentkezés szükséges. Címkéinket, megjegyzéseinket bármikor törölhetjük, módosíthatjuk, a más felhasználó által felvetteket azonban nem szerkeszthetjük; a rendszer adminisztrátorának van lehetősége a hibás, oda nem illő címkék javítására, törlésére.

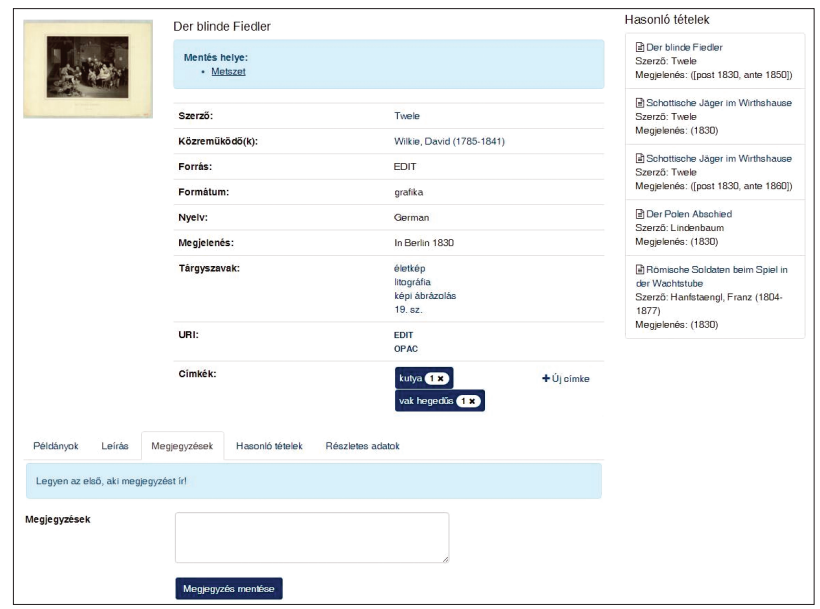

9. ábra. Címkék és megjegyzés hozzáfüzése

A rekord teljes nézeténél a szerző nevére kattintva további információkat tudhatunk meg az adott személyről, például a további műveinek kilistázása mellett a Wikipedia által biztosított életrajzi adatokat is megtekinthetjük (10. ábra). 


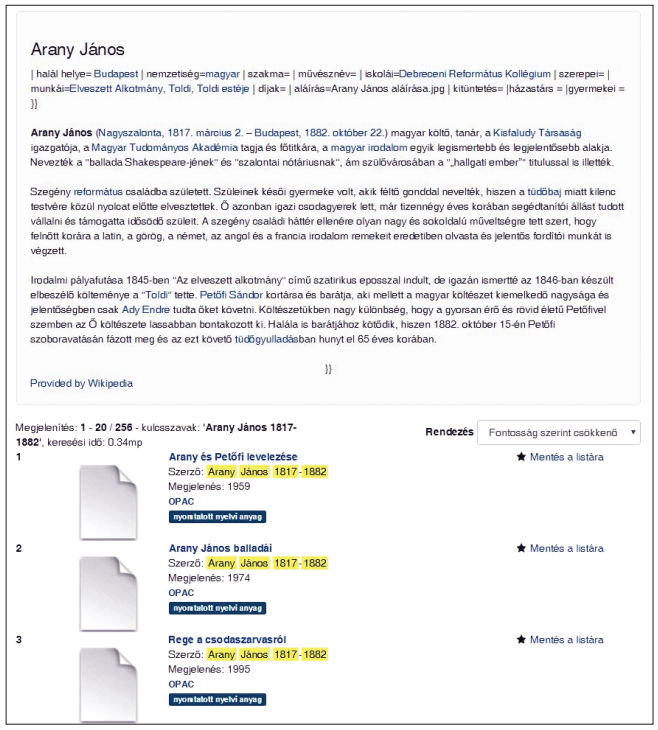

10. ábra. Wikipedia szócikk

A perzisztens, állandó URL-ek lehetőséget adnak a felhasználónak arra, hogy kereséseit vagy rekordjait megjelölje (könyvjelzőzze), így biztosítva a korábban meglátogatott oldalak könnyü visszakeresését. Az olvasó elmentheti vagy felcímkézheti a rekordokat a Zotero hivatkozáskezelö szoftverrel, így egy helyen tárolhatja azokat.

A VuFind számtalan nyelven elérhetö, saját fordítások is könnyen készíthetők. Sőt, amennyiben szeretnénk megváltoztatni a meglévő nyelvnél használt megfogalmazást, azt is megtehetjük.

A kereséshez, az adatok eléréséhez és számos egyéb funkció kihasználásához a rendszer többféle lehetőséget kínál. Egyidőben megoszthatjuk rekordjainkat más intézményekkel OAI szerveren keresztül, VuFind algoritmusokkal kereshetünk az Open Search által, és amennyiben teljes hozzáférést szeretnénk az indexelt adatokhoz, használhatjuk a beépített kereső és indexelő motorját, a Solr-t. ${ }^{6}$

\section{További beállítások, fejlesztések}

A VuFind számos hasznos, és a felhasználók által kedvelt funkciót tartalmaz, azonban adódtak olyan jellemzők, melyekre nem, vagy csak részben volt szükségünk, illetve néhány esetben indokoltnak tünt egy-egy kisebb átalakítás elvégzése.

A rendszert az egyéni igényeink szerint, a különböző elvárásoknak megfelelöen alakítjuk, s ennek révén a nyilvánosan elérhető csomagból hiányzó magyar fordítást a számunkra szükséges mértékben pótoltuk. A teljes, vagy más szóval

\footnotetext{
${ }^{6}$ VuFind. Forrás: https://vufind.org/vufind (2016. augusztus 22.)
} 
rekordnézeten is több változtatást végeztünk: nagyméretü képet illesztettünk be, a főbb adatok alatt lévő Hasonló tételek fülnél egységes méretü képeket jelenítünk meg, beillesztettünk forrásra (EDIT, OPAC) mutató URL-eket is. A teljes nézet felső menüsorában Megosztás menüpontot helyeztünk el (11. ábra), a Leirás fülről a főbb adatok közé helyeztük át a fizikai leírást.

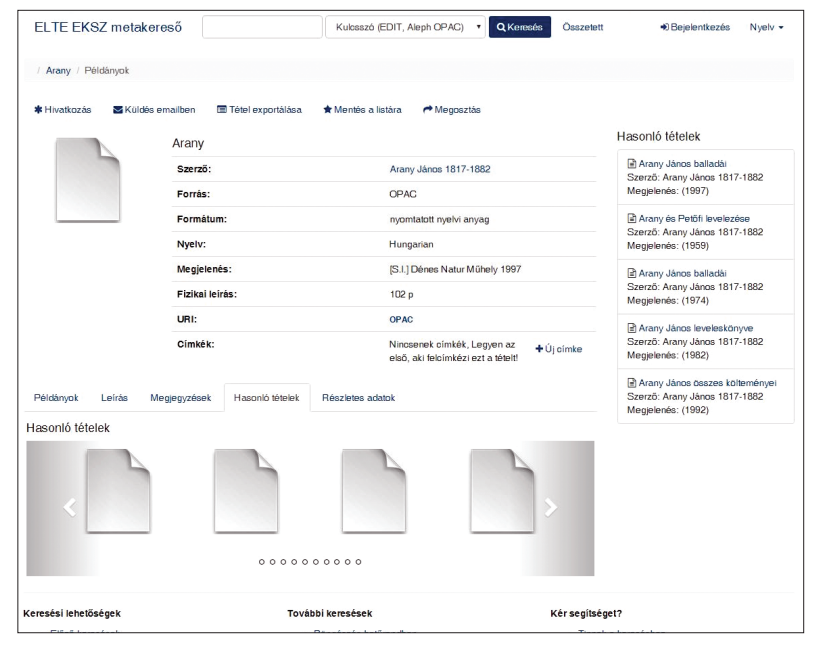

11. ábra. Hasonló tételek

Az integrált könyvtári rendszerből áttöltött kötetrekordok Kapcsolódó példányok mezőibe beillesztettük a fejrekordra mutató linket, a fejrekordba pedig a kötetrekordra mutató linket.

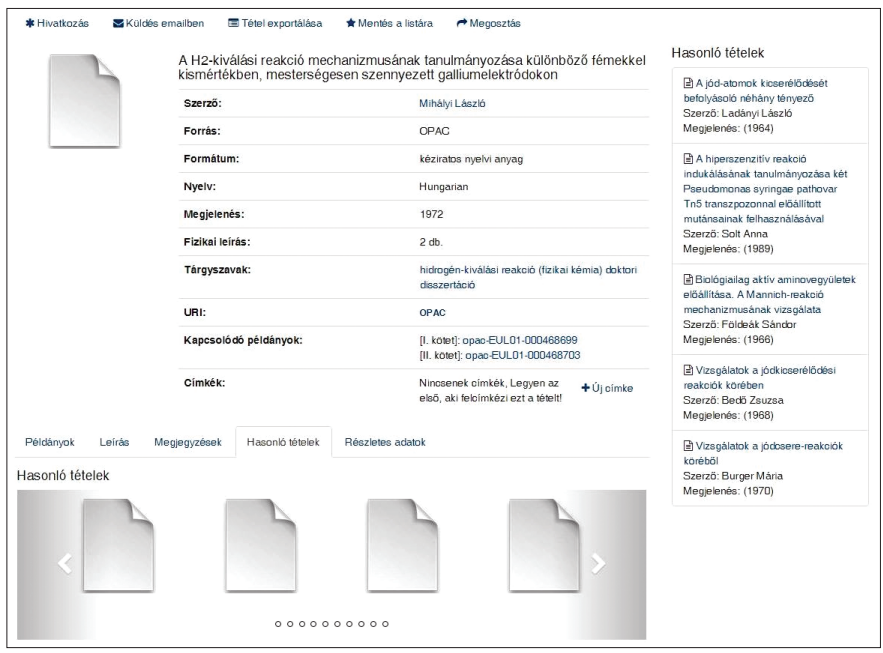

12. ábra. Kapcsolódó példányok 
A listákat vagy tételeket e-mailben továbbíthatjuk, az SMS küldési lehetöséget azonban megfelelő szerver hiányában letiltottuk. Ugyanakkor az alapértelmezetten letiltott BibTex és RIS export formátumok használatát engedélyeztük. Emellett a kiválasztott tételeket, vagy akár teljes listákat exportálhatjuk még Refworks, EndNote vagy EndNoteWeb bibliográfiakezelő rendszerekbe (13. ábra).

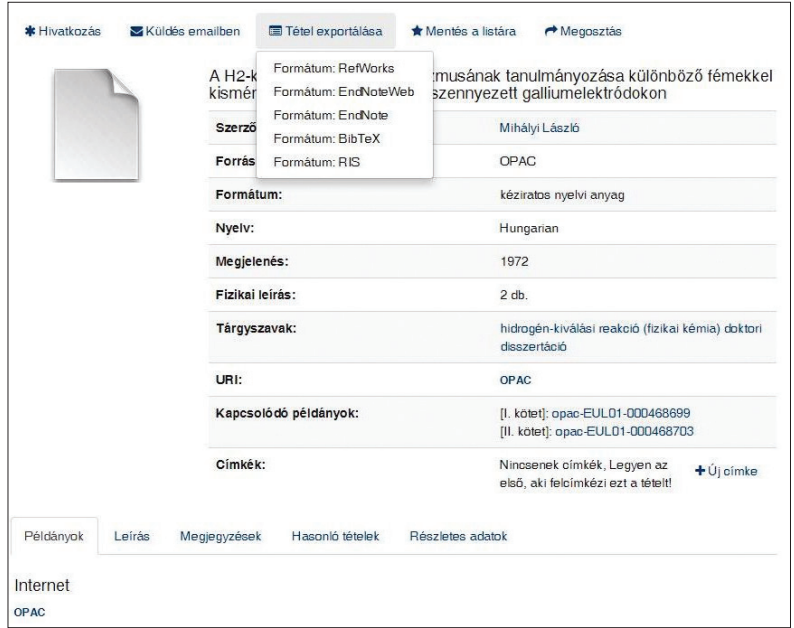

13. ábra. Tétel exportálása

Bejelentkezésnél http-ről a biztonságosabb https protokollra váltunk, valamint reCaptcha-t (14. ábra) használunk a scripttel történő, tömeges felhasználói regisztrációk megakadályozására.

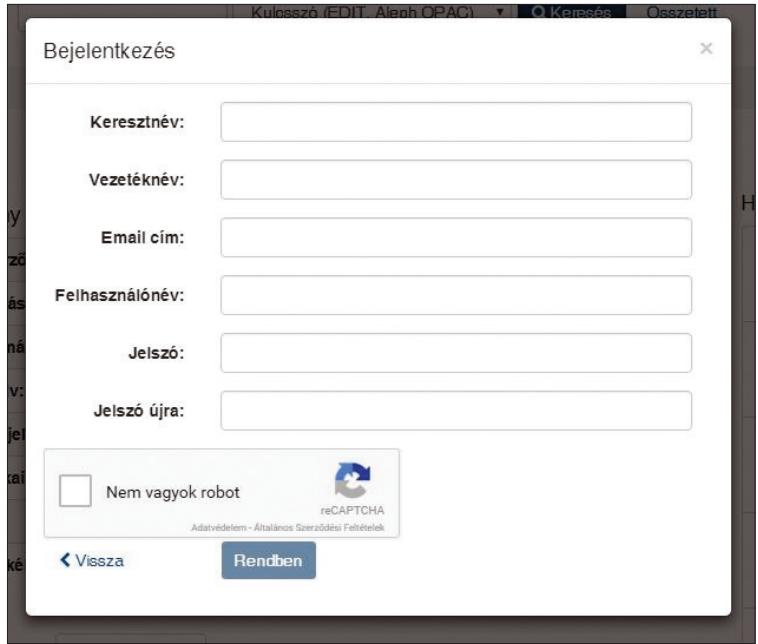

14. ábra. reCaptcha a bejelentkezésnél 
A VuFind lehetőséget biztosít a felhasználói regisztráció, ill. bejelentkezés letiltására is, de ezzel elvész a kereső közösségi használatának lehetősége. A bejelentkezett felhasználók által végezhető funkciók (úgymint a címkézés, megjegyzés hozzáfüzése, keresési kulcsszavak vagy tételek mentése) külön engedélyezhetők/letilthatók, de erre csak globálisan, az összes felhasználóra vonatkozóan van lehetőség.

\section{Hogyan tovább?}

A rendszer kialakításánál fokozottan figyelünk az egyenlő esélyü hozzáférés biztosítására, maradéktalanul figyelembe vesszük a webes akadálymentesség nemzetközi szintü hivatalos ISO/IEC 40500:2012 szabványát. A belső, azaz az ELTE Egyetemi Könyvtáron belüli, majd nyilvános tesztelés eredményeinek értékelése után elvégezzük a szükséges javításokat. A későbbiekben szeretnénk előjegyzési funkciót beállítani. Dolgozunk a nyelvek megnevezésének fordításán a nyelvre való szürésnél, a formátum megnevezések fordításán a formátum szürőnél, illetve a sorozatcím megjelenítésén az OPAC-os rekordoknál.

A VuFind a különféle adatbázisokat elérhetővé tevő moduljait drivereknek nevezi. A Web of Knowledge driver jelenleg fejlesztés alatt van (Web of Science). Részt veszünk a Science Direct API (Application Programming Interface) programjában, mely lehetöséget ad arra, hogy nyílt hozzáférésü tartalmai között is kereshessünk. Továbbá tervezzük többek között a Scopus kereső elérésének megvalósítását. A későbbiekben a duplumszürésre is nagyobb hangsúlyt fektetünk.

A felmerülő problémák folyamatos javítása is hozzájárul ahhoz, hogy valódi újgenerációs discovery szolgáltatást tudjunk nyújtani felhasználóinknak.

\section{Rezümé}

A webes alkalmazásokhoz szokott olvasóra frusztrálóan hathat egy kényelmetlen, elavult könyvtári katalógus, nem beszélve arról, hogy több adatbázisban, katalógusban kell keresnie ahhoz, hogy információhoz jusson. A közös keresők, discovery eszközök használatával a könyvtárak egypontos keresőfelületet biztosíthatnak a felhasználóknak, csökkentve ezzel a kereséssel töltött időt. A VuFind nyílt forráskódú könyvtári kereső alkalmazásával egy felületen kereshető az ELTE Egyetemi Könyvtári Szolgálat könyvtári katalógusa és az EDIT (ELTE Digitális Intézményi Tudástár), valamint előfizetett adatbázisok szolgáltatására is alkalmas. Az igényeink szerint alakítható, reszponzív, relevancia-alapú keresővel, szürési lehetőségekkel, webkettes funkciókkal igazi újgenerációs katalógust nyújthatunk a használóknak már az ELTE-n is. 


\section{OPAC 2.0 at ELTE}

\section{VuFind, the Web 2.0 Technology Based Library Search Engine}

For readers who are used to web applications, it can be frustrating to use outdated library catalogues, not to mention that they need to search in multiple databases and catalogues in order to find information. With the use of connected search engines and discovery tools, libraries can provide one box search interface for their users, reducing the amount of time they have to spend with searching. With the use of the open-source library search tool called VuFind the catalogue of the ELTE University Library Services and EDIT (ELTE Digital Institutional Repository) can be searched on the same interface having an opportunity to use subscription based databases at the same time. From now on we can provide a next generation catalogue for users at ELTE that is responsive, can be modified on demand, has relevance based search, filtering options and web 2.0 functions.

VIRÁG GABRIELLA

EDIT központi adminisztrátor

ELTE Eötvös Loránd Tudományegyetem Egyetemi Könyvtár ORCID: 0000-0002-3942-5212 